\title{
近代上海港における日本郵船会社による港湾施設建設過程 THE CONSTRUCTION PROCESS OF WHARF FACILITIES OF NIPPON YUSEN KAISHA IN MODERN SHANGHAI PORT
}

\author{
陳 雲 蓮*, 大場 修** \\ YunLian CHEN and Osamu OBA
}

\begin{abstract}
Shanghai Port is famous as the trade port since 1840 s, but even now the construction process of this port is not very clear. So this paper is to make the problem clear by focusing on the construction of the Nippon Yusen Kaisha Hongkew Mail Wharf in 1880s. As known, Hongkew mail wharf was the first wharf of the Modern Japan in Shanghai, and to Japan, WHARF was thought as one of the basic and important conditions of Shanghai Advancement.

As a new comer to Shanghai port, Nippon Yusen Kaisha was very difficult to build wharf facilities in Hongkew harbor. In order to place their new pontoons and landing spaces, after leased the waterfront of the Shanghai Japan Consulate which was next to Hongkew Mail wharf, Nippon Yusen Kaisha had to negotiate with the Municipal Council of international settlement. Because Hongkew Mail Wharf located at the North Yangtze Road complex, where Woo Chang road pontoon that used by many Chinese also existed. And the Municipal Council who built the North Yangtze Road did not agree Nippon Yusen Kaisha to place their new facilities opposite the road. Because they thought when Nippon Yusen's facilities placed, the access from Wang Po River to North Yangtze road or Woo Chang Road pontoon will be closed, and results that foreigner boats or Chinese boats can not use the waterfront of Hongkew Harbor.

So how did Nippon Yusen Kaisha solute those problems? Here, we focused on the company's negotiation strategy and the arrangement of their new pontoons' proposal to get permission from Municipal Council. Only through these analyzes, it is thought that the construction process of HongKew Mail wharf and the mean of the work carried out by Nippon Yusen Kaisha in Modern Period will be clear.
\end{abstract}

Keywords: Nippon Yusen Kaisha, Shanghai Port, North Yangtze Road New Pontoons, Foreign Ministry of Japan, Municipal Council, Japan's Consulate in Shanghai 日本郵船会社，上海港，北揚子路新栈橋，日本外務省，工部局，上海日本領事館

\section{1 研究の背景と目的}

明治末期の日本にとって、上海港は上海進出の基盤条件として位 置づけられ重視された ${ }^{1}$ 。しかし、日本が同港の港湾施設を実質的 に機能させるためには、土地使用権はもとより、水面使用権、さら には港湾施設が面する道路使用権の獲得が、その前提条件として重 要であった。しかし、日本側がそれらの港湾諸権利をどのように取 得したのか、その具体的なプロセスは明らかになっていない注2) 近代上海港は、1920 年代まで、世界第四の貿易港として発展した 注3)。しかし、その港湾施設の建設過程自体についても、先行研究と しては『上海租界志』注4しか見当たらない。同著も、上海港につい ては 1860 年代以降の同港全体の港湾施設の大まかな建設過程や、 1920 年代の英米仏日本による上海港の使用割合を紹介寸る程度で ある。上海租界にとって必要不可欠なインフラである上海港の空間 構成、港湾施設整備の計画や建設の過程、及び近代上海の都市空間 における上海港の意味、等に関しては、これまでほとんど検討され ていないのが実情である。

そこで、本稿は近代上海港について、日本による港湾施設の整備 状沉を上海租界という都市空間の視点から検討寸る。そのために、 本稿では近代日本海運業を代表する日本郵船会社に着目し、同社に よる上海港港湾施設の計画案、及びその計画案を実現させるための
各種使用権の取得過程を解明する。これにより、近代上海港の整備 過程についてその一端を明らかにすることができると考えた。その 上で、日本郵船による上海港での権利確定及びその拡張過程が、近 代日本にとってどのような意味を有していたのかについて検討する。 本稿では、主として、1888 -90 年における日本郵船会社による虹 口碼頭(Mail Wharf)の建設過程に着目寸る。虹口碼頭は、日本が上

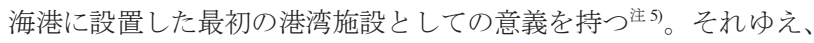

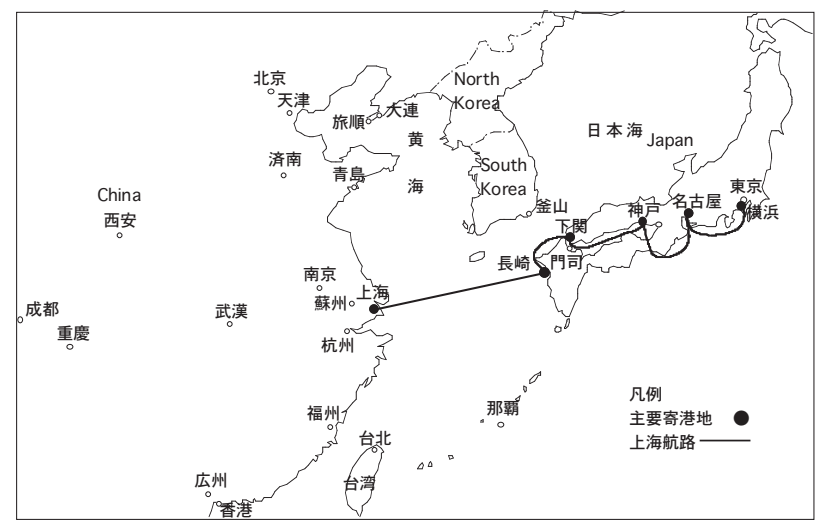

図 1 近代日本郵船会社の上海航路 $\mathrm{S} 11$ 年日本郵船の上海航路案内より
* 京都府立大学人間環境科学研究科 博士後期課程 $\cdot$ 学修

** 京都府立大学院 教授.工博
Graduate School, Kyoto Prefecture Univ., Doctor Course

Prof. of Kyoto Prefecture Univ., Dr. Eng. 
上海虹口港の立地条件や使用状況、及び日本郵船会社による当港で の港湾施設の計画内容を分析し、計画を実現させるための水面使用 権、道路使用権、建設許可の取得過程等について、すでに虹口港に おける既得権を有していた上海領事館（日本外務省直轄）、及び英米 租界の工部局との交渉過程、交涉戦略から追求したい。

その上で、一連の交渉過程や交渉主体双方の思惑がいかに上海虹 口港における実際の施設空間に反映されたのかについて検討寸る。

\section{2 研究方法と史料概要}

1888 年における日本郵船会社による虹口港再整備の計画内容や、 虹口栈橋の水面使用権と河岸使用権の取得に関しては、明治 21 年 『清国上海領事館前面二於テ日本郵舩會社二於テ借用請願一件』注 6 を使用する。同史料には、日本郵船会社社長が外務省に提出した上 海総領事館前面の河岸及び水上使用権の借用に関する請願書や、外 務省のそれに対する回答書及び上海日本総領事館の意見書、1888 年 に作成された日本郵船会社虹口碼頭の附近見取図が収録さている。 それにより、同年時点における日本郵船会社の上海港での港湾施設 の計画内容を始め、日本外務省、上海日本総領事館の上海港での港 湾施設の建設に関寸るそれぞれの見解等が読み取れる。

一方、倉庫及び栈橋の面寸る道路使用権の取得過程や 1890 年の港 湾施設の計画内容については、「The Minutes of Shanghai Municipal Council (North Yangtze Road New Pontoons)」（1890 年）注7)を用いる。 同史料には、上海虹口港における港建設をめぐる日本郵船と英工部 局との交渉過程が詳細に記録されている。それらにより、日本郵船 の港建設計画と工部局との利益衝突と和解にいたる両者の交涉過程 が明確になると考える。

また、「CADASTRAL PLAN OF THE HONGKEW SETTLEMENT 1890」と「LAND ASSESSMENT 1890」注8)を援用しつつ、上海港の 全体構成と日本郵船会社の虹口碼頭との位置関係を分析する。

\section{3 日本郵船会社虹口碼頭の立地条件と使用状況}

本節は、日本郵船会社の虹口碼頭の立地条件、英米系港湾施設と の位置関係、土地、道路、水面の使用状況から、虹口碼頭の特徴を 分析した上で、同社の直面していた課題を整理しておきたい。

\section{3-1 立地条件}

日本郵船会社虹口碼頭の立地条件及び英米による上海港の使用状 沉を分析するために、「LAND ASSESSMENT 1890」及びそれに対応 する「CADASTRAL PLAN OF THE HONGKEW SETTLEMENT 1890」を使用する。「LAND ASSESSMENT」には、虹口地区の敷地 番号、所有者及び登録領事館が記録されている。「CADASTRAL PLAN OD THE HONGKEW SETTLEMENT」との照合により、1890 年時点における上海虹口地区の各国の港を明確に確認できた(図 2)。

日本郵船会社虹口碼頭の位置する北揚子路虹口港は、上海租界地 の中心であった英租界(English Settlement)に近く、背後の虹口地区へ の上陸も極めて便利な所に位置していることが 図 2 から読み取れ る。一方、上海虹口地域全体の港湾施設に着目すると、Shanghai and Hong Kew Wharf をはじめとする主要な英米系の大規模港湾施設は、 Hong kew Creek を越えた東地区に集中していたことがわかる。そし て、日本郵船会社虹口碼頭は、英米系の港湾施設と比較した結果、 Wang Poo River に直面する幅は狭く、奥行も浅いことが一目瞭然で ある(図 2)。しかし、1890 年時点で、図 2 が示している港湾施設よ り東の地区は、まだ十分埋め立てられていなかったため注9)、上海で 港湾施設を確立するには、日本郵船会社は既存の虹口碼頭を拡張す る他に方法はなかったと考えられる。そして、日本郵船会社が位置 する北揚子路(North Yangtze Road) ${ }^{\text {ia }}{ }^{10}$ 虹口港は、中国人に最も多く使 用されていることも事実であった (後述)。

\section{3-2 使用状況}

まず、1888 年日本郵船会社の虹口地所の土地使用状況に着目した い(図 3)。西側から東側へ、順番に日本領事館、米国領事館、日本郵 船会社上海支店、米国源船会社(英語名不明)が黄浦江に面して立ち 並んでいることが分かる。当時点で、日本郵船会社の地所は、武昌 路(Woo Chang Road)と青浦路(Tsing Po Road)との間の三つの街区を 占めている。ただし、武昌路と閔行路(Min Hang Road)との間の地所 は、米国領事館に貸し出していたことが同図からわかる。

次に、郵船会社の虹口碼頭をめぐる各種都市基盤の権利について 整理しておきたい。北揚子路は工部局が建設し、その管理権も工部

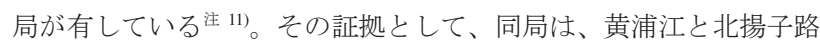
との間に、鉄の柵(Iron railing)を設置していた。更に、閔行路前の「控 船用小栈橋」は武昌路栈橋と称され、それも公共施設として使用さ れていた (6-1 節の史料 9-(2)を参照)。

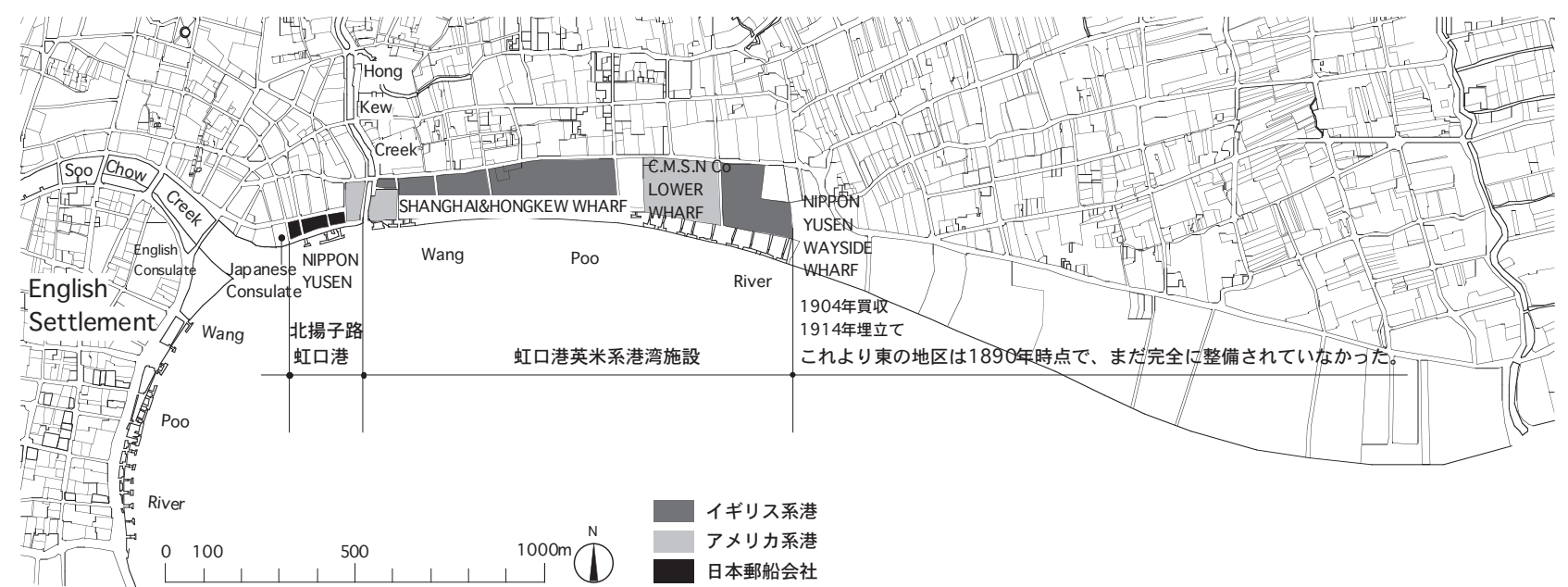

図 21890 年における上海港の各国の港施設分布状況 CADASTRAL PLAN OF THE HONGKEW SETTLENENT 1890 より作成 


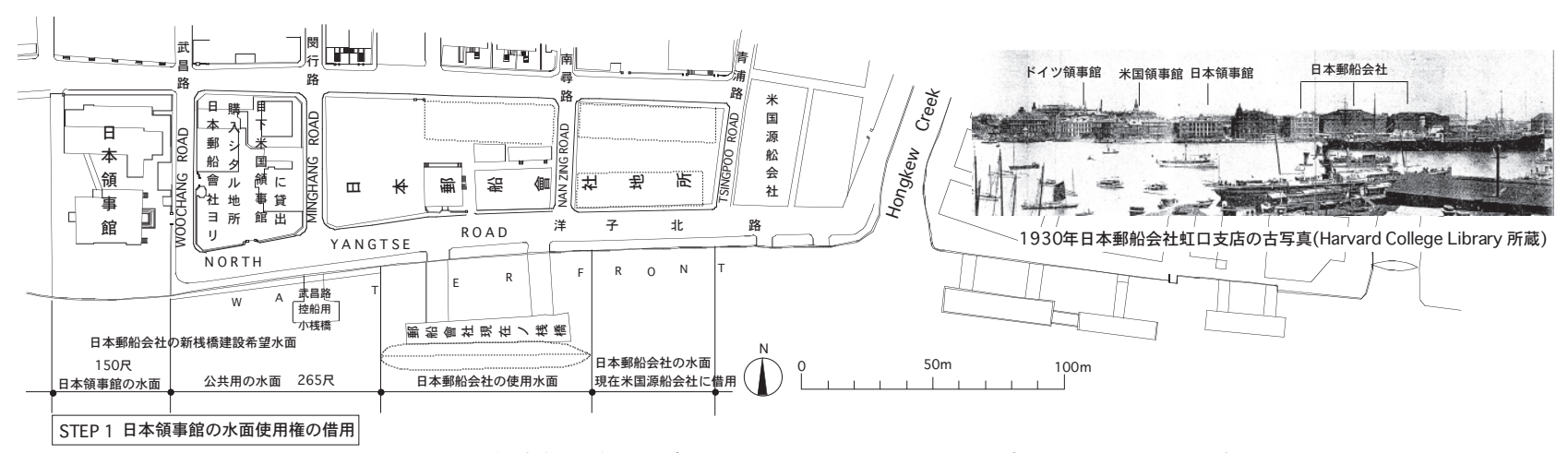

図 31888 年日本郵船会社上海虹口支店の附近見取図 原図 (外交史料館所蔵より) 作成

最後に、虹口碼頭の水面利用状況を把握しておきたい。青浦路と 南尋路(Nan Zing Road)との間の土地前面の水面は郵船会社が所有す るが、米国の源船会社が借用していた(図 3)。それに隣接する西側に、 郵船会社の大栈橋、工部局管理の公共用の「武昌控船用ノ小栈橋」 が存在している。いわば、1888 年時点で、郵船会社の地所は、武昌 路と青浦路との間まで拡大したものの、使用可能の水面は、実際は 郵船会社の栈橋の前面とその周辺しかないと考えられる。

以上、本節では、上海虹口地区全体の港湾施設の空間的特徴を示 した。その結果、日本郵船会社は、虹口港の立地条件、上海日本領 事館との位置関係、工部局における北揚子路の既得権、水面の利用 状況などといった複雑な問題を抱えていたことを明らかにした。

\section{4 虹口碼頭整備のための交渉プロセス}

日本郵船会社は、図 4 の示寸活動を行なっていたことが 2 節で取 り上げた研究史料群の解読より確認できた。本節では分析の便益上、 その活動の概要をまず説明しておきたい。第 1 の作業として、日本 外務省及び日本上海領事館と交涉して、領事館前面水面使用権を借 用し、第 2 には道路使用権及び建設許可を取得すべく工部局に申請 する。これら一連の交涉を経て、日本郵船会社は初めて実質的に虹 口港での権利を確立したことになる。交涉過程の具体的な内容は、5、 6 節にて詳細に追求していく。

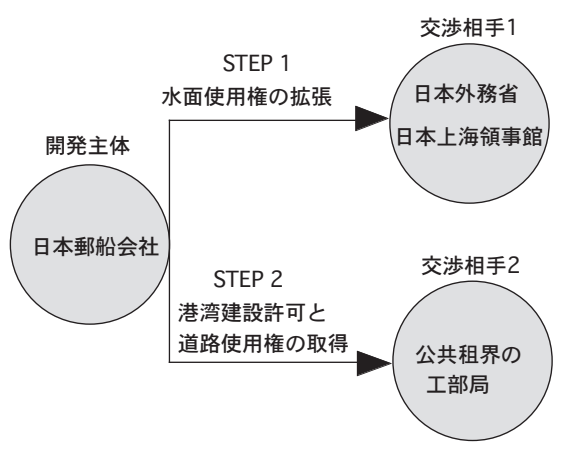

(1)『清国上海領事館前面二於テ日本郵船會社二於テ借用請願一件』

(2) IThe Minutes of Shanghai Municipal Council (North Yangtze Road New Pontoons)」より作成

図 4 日本郵船会社の港湾施設の建設過程モデル図 (図中の STEP1、STEP2 はそれぞれ図 3 と図 5 と対応する)

\section{5 虹口碼頭の水面使用権の拡張}

港湾権利を確立寸るための第 1 ステップは、水面使用権の拡張で ある。日本郵船会社は、まず、上海日本総領事館前の水面への拡張
を目論んでいた。本節では、1888 年港湾施設の計画案を示した上で、 上海日本総領事館前の水上権の借用をめぐる日本郵船会社と上海日 本領事館及び日本外務省との交涉過程を検討する。

\section{5-1 1888 年における日本郵船会社の虹口碼頭新計画}

史料 1 からは、虹口地所の拡大と共に、大栈橋の増設も計画され ていることが読み取れる。1888 年の計画では、新規買入した地所米 国領事館に貸し出している)の前面に 1 ケ所、日本領事館の前面に 1 ヶ所、計 2 ヶ所の大栈橋の新築が計画されていた(史料 1 、図 3)。

\section{史料 1 明治廿一年六月十五日 在上海 領事高平小五郎} 去四月三十日発送第五十六号貴信 $コ 以$ 來訓有シ郵船會社栈橋建築 場ノ義二付テ既二第五十七号拙諫ニテ回申致シタ処数日前該社支 配人来館...(中間略)該支配人八図面 7 差出シ現在ノ栈橋ヨリ当館 地東隅二即于該社新規買入地ノ水面二於テ一個ノ栈橋 7 新築シ更 三当館地ノ水面二於テ一個 7 増築シ都合三個二致度趣卜ノ事二付 ケ果シテ右様ノ計劃ナレハ最初拙官ヨリ本者へ回申ノ致方モ有リ ノ趣ヨ述テル八右図面八朱 $\square$ 二有旨(下線は筆者より)

計画実現のためには、日本領事館前面の水面が極めて重要となる。 上海虹口港での新栈橋計画に応じ、東京日本郵船会社本社社長の森 岡昌純は、早速外務省通商局に「清国上海領事館前面二於テ日本郵 船会社二於テ借用請願書」(史料 2 )を出した。森岡は、上海港におけ る日本領事館と郵船会社の敷地が接する約 150 尺(45m)の河岸地及 び水面は栈橋建設上に極めて重要な場所柄であり、その貸与を外務 省に請願すると同時に、港湾業務はなるべく静穏に行い、領事館に 対する不都合を起こさない等を主張している (史料 2)。

\section{史料 2 明治二十一年四月廿六日 日本郵船會社長森岡昌純 外務大臣伯爵大涱重信 宛の請願書}

在清国上海港日本領事館ノ御所所有二属スル前面ノ河岸別紙繪図 面之通几ソ百五十呎八全港弊社所有ノ河岸二連接シ弊社業務上殊 二栈橋建設上極メテ必要ノ場所柄二付特別ノ御詮議 $コ 以$ 河岸并水 面共弊社へ御貸下被成下候様仕度然ル上八拜借二係儿約定等屹度 遵奉可仕八勿論業務取扱ノ際静穏ヨ旨卜シ領事館二對シテ不都合 等決シテ相掛間敷候又此件ニ関シテハ沿街住民二於テモ異存無之 趣二有候間何卒願意御聴許被成下度別紙繪図面相添此段奉願候.

\section{5-2 外務省及び上海日本領事館の判断}

しかし、日本上海総領事高平小五郎は、日本郵船会社の水面借用 の件には反対であった。その反対理由に焦点を当てたい。

まず、日本領事館前面の全体には、交際上の必要から芝生を植え 庭苑を造り立てている。当地のような賑やかな所では、交際のため の庭苑は種種の用途を有すると総領事は主張する(史料 3-(1)。 
また、日本郵船会社が借用を希望する河岸地は、以前、公道(北揚 子路と考えられる)新築の際に、先任の総領事が上海居留地会への土 地の譲渡を拒否した経緯があることから、もし郵船会社に土地を貸 すことにならば、上海居留地会の不信感を招くおそれがあるとする (史料 3-(2) 。

最後に、領事館の前面に栈橋を建設することになれば、領事館前 面一体は郵船の繋ぎ場所となり、領事館の体裁を損ない快適性を欠 くことになると指摘する(史料 4 )。

\section{史料 3 明治廿一年五月八日 在上海 領事高平小五郎}

送第五十六号貴信茲當館前面二河岸地百五拾尺郵船会社ニテ借 用致度趣願書二付ケ其許否如何二関シ拙官意見 3-1) 右河岸地百五拾呎八即千当館前面ノ地ノ総体ノ幅員ニテ目 下芝居Э植付ケ庭苑二作立 $\square$ 成居ノ $\square \square$ 八夏期二 $\square$ 交際上必要二 有之為ナラス当地ノ如キ熱闹ノ地二在テハ館特ニゴ家族等一同ノ 為入種種ノ用途习有之二付。

3-(2) 先年上海居留地會ヨリ公道新築ノ為所望 $\square \square$ 先任領事ニヨ リ謝絶致事有之趣二付ケテハ今日二於テ郵船會社二貸渡シ八該居 留地会二對シ不信二嫌ナキ能ハス

\section{史料 4 明治廿一年六月十五日 在上海 領事高平小五郎}

(...前略)該支配人 7 居然ル之右図面若シ採用ニ成レ八該社ニテハ シテモ全体/水面 $\ni$ 借用旨卜致処仮全水面シテモ当館/前面一体 郵船/繋泊場卜成レハ体裁ヨ損シコンフオルトヨ久キ不都合勘上 口若本者ノ裁令ニロフヘキハ勿論ノ義シテ敢テ拙官ノ意見ヨ主張 ノ義ニ八無シ旨尚該社ノ申立テ次第モ有シ可然 $\square \square$ 理由ノ度ヨ重 シテ及具申卜也(下線は筆者)

以上より、総領事高平小五郎は、領事館の立地条件、周辺環境及 び上海居留地会との関係を考慮した上で、日本郵船による栈橋の建 設に反対したことがわかる。

しかし、外務省は上海総領事の意見を取り入れず、直ちに郵船会 社の日本領事館前面における栈橋建設計画を許可した。当時の外務 大臣大隈重信は、上海領事館前面の河岸地及び水面は日本郵船会社 にとって必要不可欠な場所として、同社への使用許可を出し、あわ せてその使用料金を使用の比例に応じて徵収し、また港湾の維持費 も全額日本郵船会社が負担するようにと指令した(史料 5)。

\section{史料 5 明治 21 年 6 月 12 日外務省 郵船會社へ指令案}

其領事館前面二河岸地并シ水面习郵船會社二於ル使用願ノ儀二 付去ル五月八日付第五十一号信习該河岸地八 $\square \square \square \square$ ノ情実 $\square$ $\square$ 并陳右ノ河岸ノ地面八該会社ニ於ル強ル必要ノ趣ニヨリ該願 書ニ対シ別紙写シ通指令右 $\square \square$ 估 $\square$ 願承申シ立テ...(中間略) 一上海領事館前面ノ水上八日本郵船會社二於テ栈橋/建設船舶） 繋留ノミニ限リ之レヨ使用スルノヨ許可スルモノトス其報酬金八 追テ実際使用ノ節近隣ノ比例ニヨリ相当ノ金額 コ上納スベシ 一該會社二於テハ其使用部分ニ属スル河中ノ保持費課税等（若シ アル中八）一切ノ義務 7 負担スベシ又八右使用ノ為ノ河岸堤防等 ヘ損害ヨ及ホスアルキハ其社ニ於テ之カ修繥費ヨ負担スベシ 一該水面ノ使用期限八明治二十一年ヨリ起算シ向ウ二十七年半卜 ス期満レ八建設物等 7 取拂シ元形ニ復スヘシ但シ右期限中卜 $\square$ 氏 領事館习興へ之力築造习取拂ハシムルノアルヘシ

その結果、上海日本総領事高平小五郎は、外務省の決定には極め て不満(史料 6)を抱えながら、「此際児戯ノ類スル報酬八勿論一切
徵収無シ方該テ特許ノ趣旨ヨ顕ニ $\square$ 紙トシ此際復申ト也」と無料で 郵船会社に領事館前面の河岸地と水面を貸し出した。外務省も日本 郵船会社に無料で水面を貸し出すようにと指令したことが史料 7 か らわかる。

\section{史料 6 明治廿一年七月十六日在上海 領事高平小五郎}

...当館ノ地所八之二反シ直二水面二連接致居二付其地先二接シ テ繋船場ヨ設ケル時八本館卜ノ距離借二数 $\square$ 二遙キサレ八昼夜喧 噪ナルヨ久レス夏期ニ於テ油煙ハ一直二館内へ散入シ植生上ノ関 係モフ少旦固有ノ美景ヨ失シ随ケ大二地価ニモ関ルヘキ義二付若 シ一私人ノ所有地ナラシメバ寧口モ地面 7 合セシ売渡ス単ニ水面 ヨ限貸与スヘキ筈無し $\square$ 共本件ノ場合に於テハ同会社ニテ事務拡 張ノ一盛挙二因リふ防止本 $\square$ 数條ノ故障アルスモ係ル $\square \square \cdots \square$ 看 之本者於テモ勿分 $\square \square$ 趣ニ拠ヨリ…此際児戯ノ類スル報酬八勿論 一切习徵収無シ方該テ特許ノ趣旨 7 顕ニ $\square$ 紙トシ此際復申卜也

\section{史料 7 明治廿一年八月十七日起草通商局 郵船會社へ指令案} 本年五月其会社ノ請願二對シ在上海帝国領事館前面水上使用ノ件 二對其破格金額八 $\square$ ル可指定旨指令/度 $\square \square$ 全般詮議ノ上其破格 全ヨ免除シ其代リトシテ右水面貸興中領事館用品 三於テ該栈橋ヨ使用スルヨ得セシムヘシ $\square モ$ 此場合ニ於テ八豫メ 其会社ニ打合スベシ

以上より、日本郵船会社は、日本外務省及び日本上海総領事館の 許可を得て、上海領事館前面の河岸地と水面を無償で使用すること ができた。領事館周辺の「美景」よりも「栈橋」を取るという日本 外務省の判断の下で、北揚子路虹口港における郵船会社の水面使用 権は郵船会社の栈橋、及び日本上海領事館の前面まで拡張され、新 栈橋建設のための水面使用権の取得に成功した。しかし、それはあ くまでも計画実現の第 1 歩であった。

\section{6 港湾建設許可と道路使用権の取得}

\section{6-1 1890 年日本郵船会社虹口港の計画案}

水面使用権の拡大の成功に続き、第 2 の作業として、日本郵船会 社は港湾施設の建設許可、特に北揚子路の使用権を得るために、公 共租界の工部局との交涉に当る。

日本郵船会社の代理人によって工部局董事会に提出された港建設 計画の通知書は、1890 年 2 月 25 日工部局会議で議論された。史料 8 はその議事録の一部である。これに基づき、日本郵船会社の 1888 年の計画に続く 1890 年の計画内容が確認できる(図 5)。具体的には、 青浦路と南尋路の間、南尋路と閔行路の間、閔行路と武昌路の間に 三つの新しい港 (Jetty)を建設する。更に、各新港の前にそれぞれ長 さ240feet(約 $72 \mathrm{~m}$ ), 幅 30feet(約 $9 \mathrm{~m})$ の鉄製栈橋、及び日本領事館前

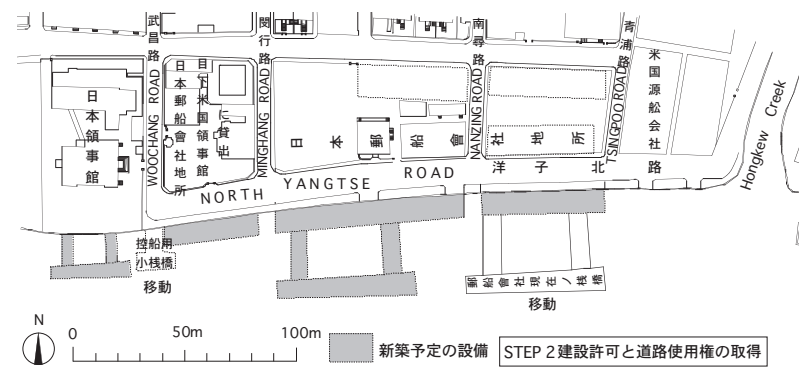

図 51890 年虹口港における日本郵船会社の港湾施設の計画図 史料 8-11の内容より作成 
に附属の栈橋(鉄製、長さ特定できない)を設置する計画であった(史 料 8-(1)の下線部分、図 5)。この新計画案により、郵船会社の虹口港 の実質的機能は、日本領事館敷地の西側の敷地境界線から青浦路ま での範囲に及ぶ。

さらに、上記の港湾施設の工事進行のために、日本郵船会社は工部 局に対し、北揚子路を黄浦江の間に設置している鉄の柵(Iron Railing) の一部分の移動を要求する (史料 8-(1) 。

史料 8 North Yangtze Road New Pontoons 1890.2.25

8-(1) Letter from the agent of the Nippon Yusen Kaisha is read intimating that he intend removing the existing pontoon to a line with the eastern boundary of their premises and placing a new pontoon to the Westward of it, 240 feet in length, by 30 feet in width, along the waterfront of their premises in North Yangtze Road. He also intends constructing three new jetties. 1 between the Qingpoo and Nanzing roads, 1 between the Nansing and MinHong roads, and 1 between the MingHong road and Woochang roads, as during the construction of these jetties there will be some interference with the sidewalks, which it will be necessary to remove a portion of the iron railing along the river, and to replace a portion to close the approach to one of the existing jetties which will then be disused. He aids for permission to carry out the works at once(下線は筆者).

8-(2) A plan showing the positions which it is proposed to place the pontoon is submitted and a report by the Surveyor stating that the proposed alteration as the position of the pontoon will shut off all access from the river to the landing spaces at the Minhang and Nanzing road which are much used by nations, (He understands that later on it is intended to place a third pontoon in front of the Japanese Consulate which will practically close all access to the Woochang Road pontoon) 8-(3) Mr. adler suggests that the Chinese authorities should stop a pontoon being placed in front of the Japanese Consulate and mentions that the Woochang road pontoon was moved there from the Ming Hang road at the request of Mr.Yuend who promised that approach should always be open for boats. Mr. Janeen said that it is the only landing place now on this side of the Hongkew creek, and point out that when the pontoons are placed as proposed not only will their moving chains, interference with boats, Steamer discharging at them will overlap the side of them.

\section{6-2 建設をめぐる日本郵船会社と工部局との対立}

工部局は、日本郵船の港計画に対し、早速拒否をした。その理由 は以下の 3 点になる。

1 日本郵船会社の埠頭及び栈橋の新計画により、中国人が多く使用 している黄浦江(Wang Poo River)から青浦路、南尋路、閔行路へのア クセスが全部閉鎖される。そして、日本領事館前に必ずや第三の栈 橋が建設されることが予想され、その結果、武昌路栈橋へのアクセ スも全部閉じられてしまうことが危惧される(8-(2)、図 5)。

2 武昌路栈橋は、黄浦江から虹口地区における唯一の船の停泊場所 (Landing place)であるが、日本郵船の新栈橋の建設により、同社の船 のチェーン(chains)や荷揚げ(discharging)等は、武昌路栈橋側の船と重 なるはずと見なされた（史料 8-(3)）。

3 中国人苦力の水汲文用の階段が閉鎖され、それらに不便を掛ける

\section{ことも考えられる(史料 9)。}

史料 9 North Yangtze Road New Pontoons 1890.3.4

The letter form the Agent of the Nippon Yusen Kaisha is again submitted. The approach from the river to the steps at the Min Hang and Nan zing Road will be closed, but Mr. Dutch says that this won't matter, as the steps are only need by goolies who came to them fill the buckets with water. (下線は筆者より)

上記 3 点、寸なわち虹口港の一般利用者、中国人労働者への支障 を理由に、工部局は同社の計画を堅く拒んだ。これに対し、日本郵 船会社の対応は注目される。

まず、郵船会社は、新築予定の栈橋と武昌路栈橋との間に、11 15 feet $(3.35$ - $4.6 \mathrm{~m})$ の距離を明確に設けるため、船のチェーンや荷揚 げ等は武昌路栈橋の障害にならないと説明した。そして、新栈橋の 突き当たりに使用者の便利を提供するための階段を設置する。なお かつ、中国側の港湾管理の役人である「河泊司(Heboshi)」からすでに 新栈橋計画の許可も得ていると工部局一反論する(史料 10)。

史料 10 North Yangtze Road New Pontoons 1890.3.4

The letter from the Agent of the Nippon Yusen Kaisha is again submitted. Mr. Brand says that he called on Mr. Dutch who informed him that he intended placing the pontoon in the positions mentioned in his letter, but that the access to the Woochang road pontoon from the river will not be interfered with, as there will be a clear space of 11-15 feet between the two pontoons. The steamers loading, or discharging at the new pontoon will not overlap the side of it. And the moving chains will be so arranged as not to interfere with boats and if the Council wish it. Steps will be placed at the end of the pontoons for the conveniences of those wishing to land at them. He also mentioned that he has got permission from the Heboshi to place the pontoon as proposed

次、日本郵船会社は、北楊子路虹口港の交通量調査を実施し、そ のデータを工部局に提示した。1890 年 3 月 10 日の AM6:00 PM11:00 の間における虹口各港の交通量は、乗客 1462 人、外国系船 舶 8 艘、小船 607 艘、水上苦力 800 人、水船 214 艘、その他の苦力 360 人であった(史料 11-(1)、表 2)。このデータから、北揚子路虹口

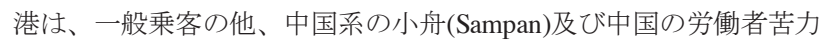
(Goolie)によく使用されていた。

すなわち、北揚子路虹口港における多量の交通量に対し、既存の 武昌路栈橋及び港のみでは対応ができなくなることを客観的に示し て、新栈橋、港湾の整備の必要性を提唱した。

表 2 1890.3.10 AM6:00 -PM11:00 の虹口各港の交通量調査結果

\begin{tabular}{|c|c|c|c|c|c|}
\hline $\begin{array}{c}\text { Passenger } \\
\text { 乗客 }\end{array}$ & $\begin{array}{c}\text { Foreign Boats } \\
\text { 外国系船舶 }\end{array}$ & $\begin{array}{c}\text { Sampan } \\
\text { 小舟 }\end{array}$ & $\begin{array}{c}\text { Water Gool ies } \\
\text { 水上苦力 }\end{array}$ & $\begin{array}{c}\text { Water Boats } \\
\text { 水船 }\end{array}$ & $\begin{array}{c}\text { Other Gool ies } \\
\text { その他苦力 }\end{array}$ \\
\hline 1462 人 & 8艘 & 607 艘 & 800 人 & 214 艘 & $360 人$ \\
\hline
\end{tabular}

このような計画案の調整と交通量調査という日本郵船の戦略によ り、工部局の対応は変化を見せる(史料 11-(2))。

史料 11 North Yangtze Road New Pontoons 1890.3.11

11-(1) The following report of the traffic at the different jetties in the North Yangtze Road on the $10^{\text {th }}$ from 6 am to $11 \mathrm{pm}$, is then submitted: Passenger 1462 Foreign Boats 8 Sampan $607 \quad$ Water goolies 800 
Water Boats $214 \quad$ Other goolies 360

11-(2) Some discussion then takes place about the right of the Council to refuse the permission applied for in the course of which it is mentioned that Mr. Dutch to determine to place the pontoon in the positions stated in his letter and that, unless the Council are prepared to carry the mater further, it would be perhaps better not to refuse his application, but it is finally decided to inform Mr. Dutch that the permission applied for cannot be granted.

さらに、日本郵船会社の交渉活動は止まらなかった。郵船会社は、 一般使用者の黄浦江へのアクセス通路を設けた平面図を工部局に提 出した。具体的には青浦路と南尋路との間、南尋路と閔行路との間 に1インチ (約 $50 \mathrm{~cm})$ 程の階段を設け、それにより黄浦江から各道 路へのアクセスや、中国人の水を汲むためのアプローチも確保でき るとした (史料 12-(1)、図 6)。上記対応策により「The company will be glad to carry out these works, or to ache upon any other suggestions which may be made either by the Harbor authorities or the Municipal Council for meeting the convenience of the public.(North Yangtze Road New Pontoons 1890.3.11 より抜粋)」と、同社は港の公共利便の向上によ り積極的に協力すると主張する。

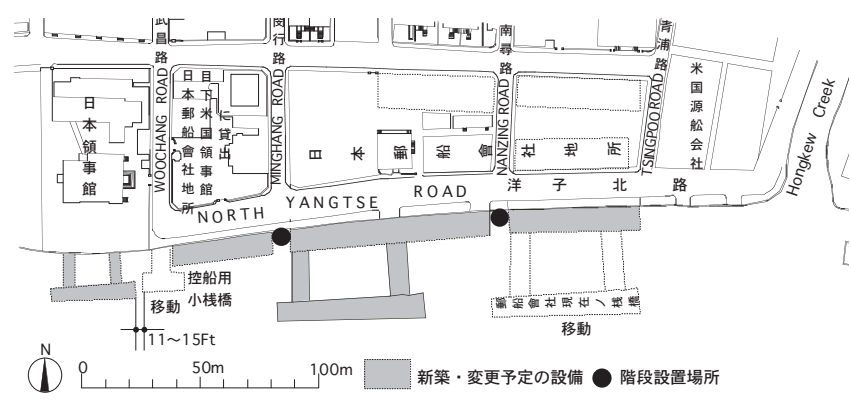

図 61890 年新栈橋計画の調整案 (史料 12-1)の内容より作成)

しかし、工部局は「近隣の所有権及び公共の権利と便利を第一に する。残念ながら工部局と日本郵船会社との間の意見はどうしても 不一致のため、この件を当港のチーフ裁判官リチャードに仲裁して もらう。裁判期間中は、一切の関連工事は中止す心゙き」(史料 12-(2))

と、依然強く日本郵船会社の港施設の新計画を拒否した。

このような工部局の態度に対し、日本郵船会社はどのように対応

したのか、次節において追求する。

史料 12 North Yangtze Road New Pontoons 1890.3.11

12-(1) a plan showing the works which the Nippon Yusen Kaisha prepared to carry out for affording to the public facilities of access to the river. These consists of one inch of steps between the Qing poo road and Nanzing roads, and one between the Nan sing road and Min hang roads, leaving the wishing steps which would be available for the drawing of water and other purpose for which they are now need.

12-(2) That the Council having regard to the right of neighboring proprietors, as well as to public right and convenience cannot sanction any interference with the access to and from roads as is proposed to be done by the Nippon Yusen Kaisha according to the plans submitted to the Council, and as there apparent to be a conflict of opinion between the Nippon Yusen Kaisha and the Council as to their respective right, the council authorities Mr.Waineiorght to intimate to Mr.Willimson, he is noting for the Nippon Yusen Kaisha that they are prepared to submit the question to the final arbitration of Sir Richard, the Chief Justice at this port. All further proceedings in connection with the works now in progress to be stopped pending the decision of the Chief Justice in the matter.

\section{6-3 日本郵船会社と工部局との和解}

工部局の裁判所への提訴という事態に対し、日本郵船側も裁判に おける工部局の仲裁内容を探りつつも、裁判期間中工事の取り下げ は出来ないとの立場をとった (史料 13 の下線部分)。実際、日本郵 船会社は、裁判期間中も工事を続けていた。例えば、既存の栈橋を 郵船会社の敷地の東境界線に移し、閔行路と武昌路の間に新しい埠 頭を造っていた (史料 14)。それに対し工部局は、「日本郵船会社が 工部局を無視することは、大きな間違いであり、北揚子路と黄浦江 との間の鉄の柵を撤去しない限り、郵船会社の新築予定の大倉庫は 機能できない」と日本郵船会社に警告した (史料 15)。

史料 13 North Yangtze Road New Pontoons 1890.5.27

Letter from Mr.Weirineon to Mr. Wainevrigh is read asking for information regarding the point which the Council wish to have submitted for arbitration but declining to agree to the work being suspended in the meantime, as the proposal much be submitted to the director in Tokyo, which involves a delay of month or two.

史料 14 North Yangtze Road New Pontoons 1890.5.25

The Surveyor reports that the Company have removed their pontoon to the Eastern boundary of their property as proposed and that it now overlap the limited of the road by about 12.5 feet, they are also removing some of the old dock line and constructing a new landing place between the Min hang and Woo chang road.

史料 15 Nippon Yusen Kaisha 1890.12.16

The Chairman adds that the Nippon Yusen Kaisha now find that they made a mistake in ignoring the Council, as they have to build a large new go-down, and made arrangements with the new Steamer Co. about wharf-age and Store-age which they cannot conveniently carry out so long do the railing along the North Yangtze road remains as it is.

結局、日本郵船会社と工部局との交渉は、1891 年 4 月の和解成立 まで続く。和解の内容は、以下の通りである(史料 16)。

1 工部局における北楊子路の権利を認めるために、日本郵船会社は 毎年、10 両の白銀を工部局に納入する。

2 公共使用者は、荷物の下し等の際に、自由に郵船会社の栈橋を使 用することが出来る。

3 日本郵船の船舶と同様に、荷物船、Sampan と他の小舟も日本郵船 のプランが示す港に入れること。これにより、西洋人、中国人も日 本郵船の港の使用権が正式に認められた。

4 日本郵船会社の栈橋と公共用の武昌路栈橋の間に明確の 45 フィ ートの距離を設ける。

日本郵船会社が和解条件に同意した結果、工部局は北揚子路及び 黄浦江との間の柵を撤去し、日本郵船の港施設の建設工事を許可し た。これにより、日本郵船の上海虹口港での権利が確立する。

史料 16 Nippon Yusen Kaisha 1891.04.01

That the company pays to the Council for the privilege accorded by 
way of recognitions of the Council right in the matter, the Sum of Ten taels per annual.

That the public be allowed all facilities for landing or cut backing gorge or passengers on, or from, the Company pontoons, not inconsistent with the free use there of by the company.

That gorge boats and Sampans and other small boats be able at all times to have free access to the jetties shown on the plans.

That a clear space of Forty Five feet be kept between the company vessel and pontoon and the public pontoon at the end of the Woochang Roads....(中間略)

The Nippon Yusen Kaisha should be specified after some discussion about the above suggestions in the course of which the Chairman points out that the rental named is a nominal Sum, and is merely intended to be an acknowledgment by the Nippon Yusen Kaisha of the right of the council over the North Yangtze Road and that on the plan the distance between the two pontoons is specified it is decided to have the letter written out and forwarded

\section{7 計画最終案}

$\lceil$ CADASTRAL PLAN OD THE HONGKEW SETTLEMENT1893」に 基づき、郵船会社の虹口港の計画最終案を復元した(図 6)。日本郵船 会社は、1888 年時点で米国源船会社に貸し出した水面を回収し、既 存の栈橋をそこに移動し、それに隣接して新栈橋を設置した。武昌 路栈橋は、武昌路と一直線の所まで移動したことが確認できる。

まず、日本上海総領事館前面の水面に、栈橋は建設されなかった。 日本領事館前面の水面使用範囲は、あくまでも武昌路栈橋の周辺の 水面に止まっていたと考えられる。これにより、領事館前面のワー ターフロントへの影響も最小限に収められた。

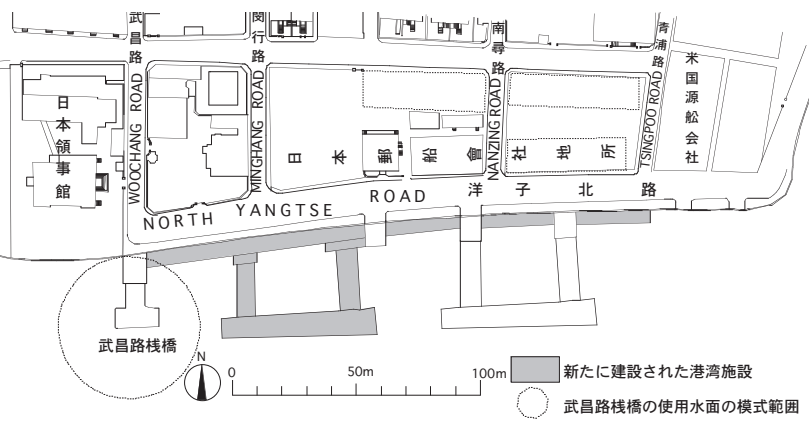

図 61893 年日本郵船会社の虹口港の最終計画案 1888 年郵船会社の虹口支店地図と 1893 年地籍図より作成

次に、工部局の意見と最終案との関係を考えたい。新栈橋と武昌 路栈橋との間の距離は具体的な数字は得られてないものの、比較的 広いことが確認できる。そして、武昌路栈橋は、図 6 で示すように 領事館前面及び郵船会社の水面を使用することが出来る。そのため、 工部局が指摘した「武昌路栈橋へのアクセスが閉じられてしまう」 ことは避けられたと考える。

虹口港の港湾整備とその構成は、日本郵船会社と上海総領事館、 及び工部局の三者間の妥協により結実した。このようにして明治末 期に整備された虹口港の栈橋、埠頭及び郵船会社の倉庫は、1945 年 の終戦まで機能し、現在も中国側の施設として使用されている。

\section{8 結論}

本稿は、日本郵船会社による近代上海虹口港での港湾施設の構成 と計画内容を明らかにしつつ、水面使用権、道路使用権及び建設許 可の取得をめぐる日本外務省、日本上海領事館、さらには公共租界 工部局との交渉過程を追求することで、明治末期の日本による上海 租界における開発実態の一端を明らかにした。

注目すべきは、本論が明らかにした日本郵船会社による既得権を 有する英米人との交渉、衝突、和解の一連の過程である。上海にお ける権利確保は、上海において後発の日本が常に直面せざる得ない 難題であった。第 3 節で取り上げたように、上海虹口港における日 本側の港湾施設は、英米系の施設と比べ決して主流ではなかった。 それでも、日本郵船会社は、戦略的に、客観的に公共の利便を主張 しつつ計画案を調整して応じ、英米人に妥協しつつも上海における 自らの権利を入手した。これにより、日本は、1888一90 年時点で上 海進出の本格的かつ重要な一歩を踏夕出した。

日本郵船会社虹口碼頭の背後の虹口地区は、近代上海の日本人街 として知られている。日本郵船会社による 1888一90 年の虹口港での 権利獲得は、まさに日本が上海市街地へと進出する重要な前提条件 を確立したことを意味する。しかも、近代日本による上海での都市 開発はまさにこの北揚子路虹口港から始まったことも、筆者らの既 往研究が明らかにしている注 12)。では、日本が虹口港から、どのよ うに上海における自らの種々の都市施設を作り上げていったのか。 今後、この点をさらに追求する予定である。

\section{注}

注 1)陳・大場「1890 - 1910 年代における上海日本人居住地の形成背景」『日本 建築学会 2008 年度学術講演梗概集 F-2』2008 年

注 2)日本郵船会社の発祥に関し、日本郵船会社編『日本郵船 50 周年史』は詳 細に記録している。1 875 年、三菱会社は米国太平洋郵船の上海航路、上 海における倉庫、港湾施設を買収し、それは、近代日本の上海航路の始 まりである。1 885 年、日本郵船会社は、三菱会社から独立し、虹口港倉 庫地所を同社より引き継ぎ、主体として上海航路を独自に運営し始めた。 注 3)後藤春美『上海をめぐる日英関係 1925-1932 年』 P18 東京大学出版会、 2006 年

注 4) 上海租界志編集委員会編,上海社会科学院出版社, pp458一459,2001 年,

注 5)虹口碼頭は、1914 年の郵船会社の匯山碼頭(Wayside Wharf)の埋立てまで には、近代日本における上海での最初の港湾施設であった。日本郵船会 社上海虹口碼頭会社は、土地 4,138 坪、事務所 - 倉庫等 14 棟、3,790 坪 の規模まで達した。(日本郵船会社貨物課編, 『我が社各航路沿革』1933 年,日本郵船歴史博物館所蔵より)

注 6)外務省外交史料館所蔵 3-12-1 史料より

注 7)上海档案館所蔵

注 8$)$ 同上

注 9)前掲 2 節の「Cadastral Plan of The Hongkew Settlement 1893」より確認出来 る。この地図には、同地区の河沿いの地区には、地籍番号が割り当てら れているものの、陸地方向の奥行が非常に浅いため、まだ完全に埋め立 てられていないことが事実である。

注 10)北揚子路の名称に関し、日本郵船会社の地図史料には「洋子北路(North Yangtze Road)」と書かれている。一方、工部局側の史料には「北揚子路 (North Yangtze Road)」と書かれている。本文では後者の名称に統一する。 注 11)北揚子路の築年はまだ不明であるが、その所有権は工部局にあることが 第 6 節の史料 16 の下線部分より確認できる。

注 12)京都府立大学人間環境科学研究科 2008 年度博士後期課程中間報告より 